\title{
A comparison between the gastric and salivary concentration of iodide, pertechnetate, and bromide in man
}

\author{
R. McG. HARDEN, W. D. ALEXANDER, J. SHIMMINS, AND D. CHISHOLM \\ From the University Department of Medicine, Gardiner Institute, Western Infirmary, and the Western Regional \\ Hospital Board, Regional Physics Department, Glasgow
}

SUMmARY The concentration of iodide $\left(\mathrm{I}^{-}\right)$and pertechnetate $\left(\mathrm{TcO}_{4}^{-}\right)$and bromide $\left(\mathrm{Br}^{-}\right)$has been measured simultaneously in gastric juice and parotid saliva. The combined gastric and salivary clearance for iodide and pertechnetate is more than twice the clearance of these ions by the thyroid gland. The concentration of the ions was in the order $\mathrm{I}^{-}>\mathrm{TcO}_{4}{ }^{-}>\mathrm{Br}^{-}$in both gastric juice and saliva. Differences exist between the secretion of iodide, pertechnetate, and bromide. Bromide, in contrast to iodide and pertechnetate, was found to be more concentrated in gastric juice than in saliva. The ratio of the iodide to pertechnetate clearance was greater in gastric juice than in saliva.

A concentrating mechanism for iodide is present in the thyroid and salivary glands and in the stomach (Wolff, 1964; Honour, Myant, and Rowlands, 1952; Schiff, Stevens, Molle, Steinberg, Numpe, and Stewart, 1947). Pertechnetate and bromide have some similar properties to iodide. Pertechnetate is concentrated in the thyroid, the salivary glands, and the stomach, and the isotope pertechnetate- ${ }^{-99 \mathrm{~m}} \mathrm{Tc}$ has been used to scan these organs (Andros, Harper, Lathrop, and McCardle, 1965; Herbert, Kulke, and Shepherd, 1965; Harden, Hilditch, Kennedy, Mason, Papadopoulos, and Alexander, 1967a; Harden, Alexander, and Kennedy, 1967). Although its secretion has been investigated in saliva (Harden, and Alexander, 1967; Harden, Alexander, Shimmins, Kostalas, and Mason, 1968), few studies have been made of its concentration in gastric juice. Bromide is concentrated in saliva and in gastric juice but its concentration has not been compared with that of iodide and pertechnetate in these organs. The aim of the present investigation was to study simultaneously in man the secretion of iodide, pertechnetate, and bromide in saliva and in gastric juice.

\section{MATERIALS AND METHODS}

Seven male subjects were studied. All were volunteers and their ages ranged from 35 to 68 years.

A solution containing a mixture of $50 \mu \mathrm{Ci}{ }^{132} \mathrm{I}, 200$ $\mu \mathrm{Ci}{ }^{99 m} \mathrm{Tc}$, and $30 \mu \mathrm{Ci}{ }^{82} \mathrm{Br}$ was injected intravenously. A Ryle's tube was passed into the stomach and the upper end was attached to a syringe. Gastric juice was aspirated continuously in an attempt to keep the stomach as empty as possible. Parotid saliva was collected using a modified Carlson-Crittenden cup. The inner chamber (diameter $10 \mathrm{~mm}$ ) was placed over the parotid duct orifice and was held in position by suction applied to the outer chamber (diameter $20 \mathrm{~mm}$ ). The subject's head was tilted forward so that any saliva ran to the front of the mouth, and he was instructed not to swallow but to spit out saliva as necessary. Parotid saliva and gastric juice were collected under resting conditions for $\mathbf{4 0}$ minutes and were discarded. Thereafter, two 15-minute collections were made from $\mathbf{4 0}$ to 55 minutes and from 55 to 70 minutes. Blood samples were taken at $42 \frac{1}{2}$ and $57 \frac{1}{2}$ minutes. The radioactivity of these samples was assumed to be the mean radioactivity of the plasma during the secretion period of the saliva and gastric juice. Even if this is not absolutely true no serious error will result as the plasma activity is falling slowly at this time interval after injection of the isotopes. Plasma, saliva, and gastric juice samples were counted using an automatic well-type counter with a single channel analyser. Each sample was counted on three occasions. First, immediately after the experiment, ${ }^{132} \mathrm{I}$ plus ${ }^{82} \mathrm{Br}$ were estimated excluding ${ }^{93 \mathrm{~m} T c}$. Secondly, this count was repeated after 24 hours during which time the ${ }^{132}$ I decayed giving an estimate of ${ }^{82} \mathrm{Br}$. Thirdly, the counting conditions were adjusted and ${ }^{99} \mathrm{~m} \mathrm{Tc}$ and ${ }^{82} \mathrm{Br}$ were estimated. When counting ${ }^{132} \mathrm{I}$ and ${ }^{82} \mathrm{Br}$ all pulses equivalent in energy to greater than $0.5 \mathrm{MEV}$ were counted.

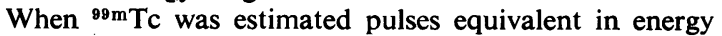
between 100 and $180 \mathrm{KEV}$ were counted. Counts for each individual isotope were obtained by solving simultaneous linear equations using a computer. The saliva/ plasma or gastric juice/plasma $\mathrm{I}^{-}, \mathrm{TcO}_{4}^{-}$, and $\mathrm{Br}^{-}$ 
ratios, and the salivary and gastric $\mathrm{I}^{-}, \mathrm{TcO}_{4}^{-}$, and $\mathrm{Br}^{-}$ clearances were calculated for each sample.

Saliva or gastric clearance $=$

Saliva or gastric juice activity $(\%$ dose $/ \mathrm{ml}) \times$ volume $(\mathrm{ml})$ Plasma activity $(\%$ dose $/ \mathrm{ml}) \times$ duration collection $(\mathrm{min})$

\section{RESULTS}

The flow rates of saliva and gastric juice did not differ significantly in the two collection periods (Table I).

TABLE I

SECRETION OF ${ }^{132} I^{-}$IN SALIVA AND GASTRIC JUICE IN SEVEN SUBJECTS

\begin{tabular}{|c|c|c|}
\hline $\begin{array}{l}\text { Flow Rate } \\
(\mathrm{ml} / \mathrm{min})\end{array}$ & $\begin{array}{l}\text { Ratio } \\
\text { Gastric Juice! } \\
\text { Plasma or Saliva! } \\
\text { Plasma }{ }^{132} \text { I }\end{array}$ & $\begin{array}{l}{ }^{132} / \text { Clearance } \\
(\mathrm{m} / / \mathrm{min})\end{array}$ \\
\hline Mean (SE) & Mean (SE) & Mean (SE) \\
\hline
\end{tabular}

\begin{tabular}{|c|c|c|c|c|c|c|}
\hline \multicolumn{7}{|l|}{ Saliva } \\
\hline 1 & $0 \cdot 15$ & $(0.04)$ & $44 \cdot 6$ & $(11.6)$ & $4 \cdot 7$ & $(0 \cdot 36)$ \\
\hline 2 & $0 \cdot 16$ & $(0.04)$ & $51 \cdot 3$ & $(18 \cdot 1)$ & $5 \cdot 6$ & $(0.86)$ \\
\hline Mean & $0 \cdot 16$ & $(0.04)$ & $47 \cdot 9$ & $(14 \cdot 8)$ & $5 \cdot 1$ & $(0.47)$ \\
\hline \multicolumn{7}{|c|}{ Gastric Juice } \\
\hline 1 & $1 \cdot 81$ & $(0.41)$ & $21 \cdot 5$ & $(2 \cdot 8)$ & $36 \cdot 7$ & $(9 \cdot 2)$ \\
\hline 2 & $1 \cdot 37$ & $(0.35)$ & $26 \cdot 0$ & $(4 \cdot 5)$ & $31 \cdot 7$ & $(6.9)$ \\
\hline Mean & $1 \cdot 59$ & $(0.36)$ & $23 \cdot 8$ & $(3 \cdot 5)$ & $34 \cdot 2$ & $(7 \cdot 6)$ \\
\hline
\end{tabular}

At the flow rates studied the saliva/plasma iodide ratios ranged from 13.8 to 154.1 (mean $47.9 \pm \mathrm{SE}$ $14 \cdot 8$ ). This was greater than the 15.8 to 50.9 gastric juice/plasma ratios (mean $23 \cdot 8 \pm 3 \cdot 5$ ). However, as a result of the greater gastric secretion rate the gastric iodide clearance was significantly greater than the clearance by the parotid gland $(\mathrm{P}<0.005)$ (Table I). Values for saliva/plasma and gastric juice/plasma ratios were similar in the two collection periods.

Compared with iodide, pertechnetate was concentrated to a lesser extent both in saliva, $27 \cdot 3 \pm 9 \cdot 8$, and in gastric juice, $11.0 \pm 1.4$ (Table II). This difference was more marked with gastric juice and the $\mathrm{I}^{-} / \mathrm{TcO}_{4}{ }^{-}$clearance ratio was significantly higher in gastric juice, $2 \cdot 2$, than it was in saliva, $1.9(\mathrm{P}<$ $0 \cdot 025$ ).

TABLE II

SECRETION OF ${ }^{99} \mathrm{~m} \mathrm{TCO}_{4}{ }^{-}$IN SALIVA AND GASTRIC JUICE

\begin{tabular}{|c|c|c|}
\hline $\begin{array}{l}\text { Ratio } \\
\text { Gastric Juicel } \\
\text { Plasma or Salival } \\
\text { Plasma }{ }^{83 \mathrm{~m}} \mathrm{TCO}_{4}^{-}\end{array}$ & $\begin{array}{l}\text { Clearance of } \\
{ }_{93 \mathrm{~m}} \mathrm{TCO}_{4}^{-} \\
(\mathrm{ml} / \mathrm{min})\end{array}$ & $\begin{array}{l}\text { Clearance Ratio of } \\
{ }^{132} / /{ }^{99 \mathrm{~m}} \mathrm{TCO}_{4}\end{array}$ \\
\hline Mean (SE) & Mean (SE) & Mean (SE) \\
\hline
\end{tabular}

\begin{tabular}{lrrrrrr}
\hline $\begin{array}{l}\text { Saliva } \\
1\end{array}$ & 24.7 & $(8.0)$ & 2.4 & $(0.19)$ & 1.9 & $(0.11)$ \\
2 & 29.8 & $(11.5)$ & 3.2 & $(0.56)$ & 1.8 & $(0.09)$ \\
$\quad$ Mean & 27.3 & $(9.8)$ & 2.8 & $(0.35)$ & 1.9 & $(0.09)$ \\
Gastric Juice & & & & & & \\
1 & 10.1 & $(1 \cdot 3)$ & 16.3 & $(3.49)$ & 2.2 & $(0.11)$ \\
2 & 11.9 & $(1.5)$ & 15.1 & $(3.78)$ & 2.1 & $(0.14)$ \\
Mean & 11.0 & $(1.4)$ & 15.7 & $(3.50)$ & 2.2 & $(0.11)$
\end{tabular}

In contrast to the findings for iodide and pertechnetate the concentration of bromide in gastric juice was significantly higher than in saliva $(\mathrm{P}<0.025)$ (Table III). The iodide/bromide clearance ratio consequently was lower in gastric juice than in saliva $(\mathrm{P}<0.025)$.

\section{TABLE III}

SECRETION OF ${ }^{82} \mathrm{Br}^{-}$IN SALIVA AND GASTRIC JUICE

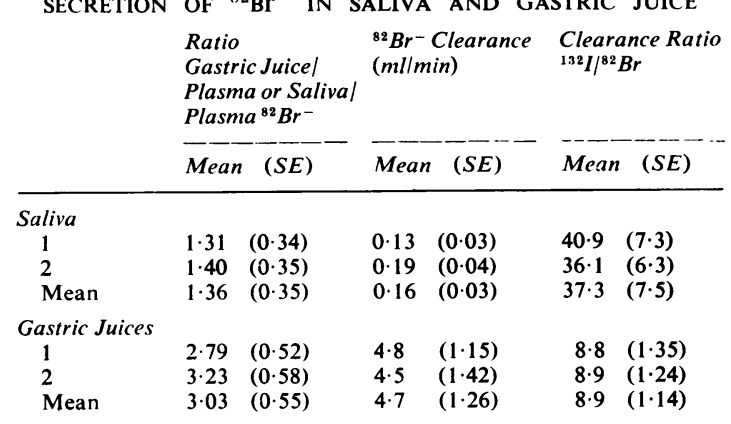

\section{DISCUSSION}

Under conditions of minimum stimulation the concentration of iodide in parotid saliva is greater than the concentration in gastric juice. This is in agreement with the findings of Honour et al (1952) and Schiff et al (1947). It does not imply, however, a more efficient iodide trap in the salivary glands, as the concentration of iodide in saliva or gastric juice depends upon the degree to which the iodide secreted is diluted by the secretion from the acini in the salivary glands and by acid-containing juice in the stomach (Brown-Grant, 1961; Brown-Grant, Cumming, Haigh, and Harries, 1965). Indeed, the iodide clearance in the gastric juice is greater than the iodide clearance by the salivary glands.

Significant quantities of iodide are cleared from the plasma by the salivary glands and stomach. Assuming that parotid: submandibular saliva iodide secretion is in the ratio 2.3:1 (Harden, Mason, and Buchanan, 1965), the iodide clearance from the combined submandibular and parotid salivary glands was $14.7 \mathrm{ml} / \mathrm{min}$ in the patients we studied. Thus the combined salivary and gastric clearance of iodide at $49 \mathrm{ml} / \mathrm{min}$ is more than double the normal thyroidal iodide clearance of $22.6 \mathrm{ml} / \mathrm{min}$ (Wayne, Koutras, and Alexander, 1964). Honour et al (1952) also reported high values with a mean rate of $42 \mathrm{ml} /$ $\mathrm{min}$. Thisiodide secreted in the gastric juice and saliva is not lost from the body as it is rapidly reabsorbed after passing into the small intestine. However, consideration of this iodide pool is of practical importance in studies of iodide kinetics. By delaying the passage of iodide to the kidneys, the gastric and 
salivary concentrating mechanisms help the body to conserve iodide. Occasionally it may have practical importance in radioiodine studies. For example, a significant proportion of a tracer or therapeutic dose of radioiodine will be lost if a patient vomits shortly after its administration. A discrepancy was recently noted in a patient between the urine excretion and body retention of ${ }^{131}$ iodide 12 hours after a tracer dose (McCall, Tim, and Frenkel, 1967). This was due to loss of $24 \%$ of the dose in tobacco which the patient chewed but never swallowed.

Pertechnetate ${ }^{89 \mathrm{~m}} \mathrm{Tc}$ is being increasingly used as a diagnostic agent in many situations as a substitute for radioiodine. Our knowledge of its metabolism in the body is, however, deficient and further studies of pertechnetate physiology and kinetics require to be undertaken. Andros et al (1965) demonstrated a difference in the faecal secretion of pertechnetate compared with iodide, and the iodide/pertechnetate clearance ratio in saliva and gastric juice in the present study represents another difference in the handling of iodide and pertechnetate in the body. Although bromide is present at greater than the plasma concentration both in saliva and in gastric juice it is less concentrated than either iodide or pertechnetate. In contrast, however, to iodide and pertechnetate the gastric juice/plasma bromide ratio measured simultaneously is significantly greater than the saliva/plasma bromide ratio. Bromide may be secreted by two mechanisms, one a specific transport mechanism which is shared with iodide and pertechnetate and another which is common to chloride. It has been previously shown that bromide may replace chloride in the gastric juice so that the acidsecreting cells of the mucosa of the stomach secrete hydrobromic acid in the same way as they secrete hydrochloric acid (Goodman and Gilman, 1955). Although concentrated less than iodide, bromide is secreted preferentially over chloride, and Gamble, Robertson, Hannigan, Foster, and Farr (1953) found bromide/chloride clearance ratios of 3.2 and 3.4 in gastric juice and 2.3 and 3.0 in saliva. In animals, bromide was found localized with iodide in the surface epithelium of the gastric mucosa (Ullberg, Appelgren, Clemedson, Ericsson, Ewaldsson, Surbo, and Söremark, 1964; Ullberg and Söremark, 1961) and in the mouse the gastric contents were found to contain the highest concentration of bromide (Söremark and Ullberg, 1960). The excretion of bromide in the gastric juice may too have practical implications. Sheils and Dyke (1964), for example, treating a patient with bromism by continuous gastric aspiration, were able to remove 140 m-equiv bromide in the gastric aspirate in contrast to a peak urine excretion of only 33 m-equiv/day.

\section{REFERENCES}

Andros, G., Harper, P. V., Lathrop, K. A., and McCardle, R. J. (1965). Pertechnetate-99m localization in man with applications to thyroid scanning and the study of thyroid physiology. J. Clin. Endocr., 25, 1067-1076.

Brown-Grant, K. (1961). Extrathyroidal iodide concentrating mechanisms. Physiol. Rev., 41, 189-213.

- Cumming, J. D., Haigh, A. L., and Harries, E. H. L. (1965). The secretion of radioactive iodide by the stomach of the anaesthetized dog in relation to total gastric blood flow and to acid secretion. J. Physiol. (Lond.), 177, 337-345.

Gamble, J. L., Robertson, J. S., Hannigan, C. A., Foster, C. C., and Farr, L. E. (1953). Chloride, bromide, sodium and sucrose spaces in man. J. clin. Invest., 32, 483-489.

Goodman, L. S., and Gilman, A. (1955). The Pharmacological Basis of Therapeutics. MacMillan, New York.

Harden, R. M., Mason, D. K., and Buchanan, W. W. (1965). Quantitative studies of iodide excretion in saliva in euthyroid, hypothyroid and thyrotoxic patients. J. clin. Endocr., 25, 957-961.

-, Alexander, W. D., and Kennedy, I. (1967). Isotope uptake and scanning of the stomach in man using $99 \mathrm{~m}$-Tc-pertechnetate. Lancet, 1, 1305-1307.

- , Hilditch, T. E., Kennedy, I., Mason, D. K., Papadopoulos, S., and Alexander, W. D. (1967a). Uptake and scanning of the salivary glands in man using pertechnetate-99m-Tc. Clin. Sci. 32, 49-55.

- , Alexander, W. D., Shimmins, J., Kostalas, H., and Mason, D. K. (1968). Quantitative aspects of the inhibitory effect of the iodide ion on parotid salivary iodide and pertechnetate secretion in man. J. Lab. clin. Med., 71, 92-100.

- - (1967). The relation between the clearance of iodide and pertechnetate in human parotid saliva and salivary flow rate. Clin. Sci., 33, 425-431.

Herbert, R., Kulke, W., Shepherd, R. T. H. (1965). The use of technetium $-99 \mathrm{~m}$ as a clinical tracer element. Postgrad. med. J., 41, 656-662.

Honour, A. J., Myant, N. B., and Rowlands, E. N. (1952). Secretion of radioiodine in digestive juices and milk in man. Clin. Sci. $11,447-462$.

McCall, M. S., Tim, L., and Frenkel, E. P. (1967). Chewing tobacco and radioiodine. Lancet, $1,902$.

Schiff, L., Stevens, C. D., Molle, W. E., Steinberg, H., Kumpe, C. W., and Stewart, P. (1947). Gastric (and salivary) excretion of radio-iodine in man (Preliminary Report). J. nat. Cancer Inst., 7, 349-354.

Sheils, W. S., and Dyke, R. W. (1964). Bromism treated by gastric stimulation and aspiration. Arch. Int. Med., 114, 71-75.

Söremark, R., and Ullberg, S. (1960). Distribution of bromide in mice. An autoradiographic study with $\mathrm{Br}^{82}$. Int. appl. J. Radiat. and Iso., 8, 192-197.

Ullberg, S., and Söremark, R. (1961). Autoradiographic localisation of bromide $(\mathrm{Br}-82$ and $\mathrm{Br}-80 \mathrm{~m})$ in the gastric mucosa. Gastroenterology, 40, 109-112.

_-, Appelgren, L. E., Clemedson, C. J., Ericsson, Y., Ewaldsson, B., Surbo, B., and Söremark, R. (1964). A comparison of the distribution of some halide inns in the body. Biochem. Pharmacol., 13, 407-412.

Wayne, E. J., Koutras, D. A., and Alexander, W. D. (1964). Clinical Aspects of Iodine Metabolism. Blackwell Scientific Publications, Oxford.

Wolff, J. (1964). Transport of iodide and other anions in the thyroid gland. Physiol. Rev., 44, 45-90. 